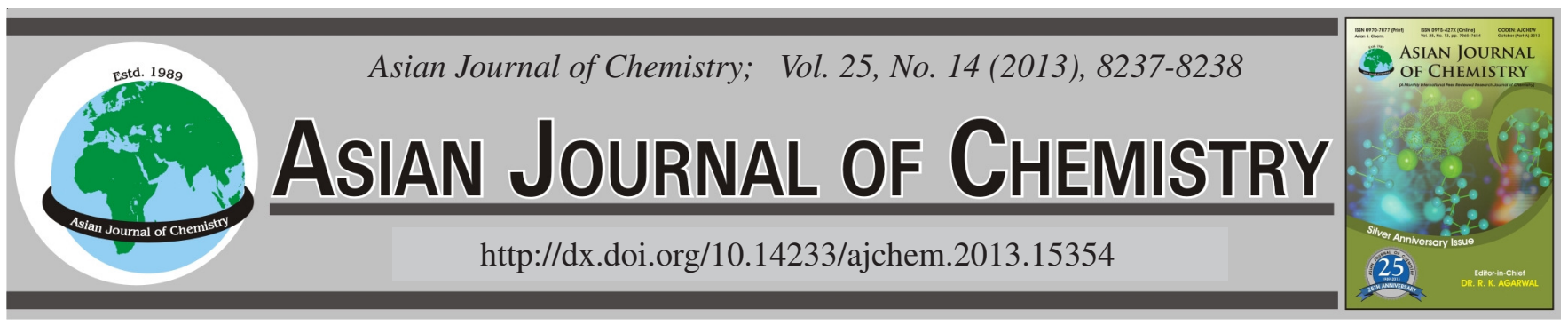

NOTE

\title{
Synthesis and X-Ray Diffraction of a Ternary Plumbum Complex
}

Jian-Hong BI ${ }^{*}$, HuA-Ze Dong and Yu-Miang WANG

Deparment of Chemistry and Chemical Engineering, Hefei Normal University, Hefei, P.R. China

*Corresponding author: E-mail: bi010101@126.com

(Received: 18 February 2013;

Accepted: 12 August 2013)

AJC-13921

A new ternary plumbum complex $\left[\mathrm{Pb}(\text { phen })_{2}\left(\mathrm{NO}_{3}\right)_{2}\right]$ (phen $=1,10$-phenanthroline) has been synthesized and characterized by IR spectra
and single-crystal X-ray diffraction. The crystal belongs to monoclinic crystal system and has space group P2(1)/n with unit cell parameters:
$\mathrm{a}=16.7304(15) \AA, \mathrm{A}=7.7529(7) \AA, \mathrm{c}=18.1308(17) \AA, \alpha=90^{\circ}, \beta=98.2170(10)^{\circ}, \gamma=90^{\circ}, \mathrm{V}=2327.6(4) \AA^{3}, \mathrm{Z}=4, \mathrm{M}_{\mathrm{r}}=691.62, \mathrm{D}_{\mathrm{c}}=$
$1.974 \mathrm{Mg} / \mathrm{cm}^{3}, \mu=7.303 \mathrm{~mm}^{-1}, \mathrm{~F}_{(000)}=1328, \mathrm{~T}=298(2) \mathrm{K}, \mathrm{R}=0.0306, \mathrm{wR}=0.0574$ for 11276 reflections with $\mathrm{I}>2 \sigma(\mathrm{I})$. In terms of the
crystal structure, $\mathrm{Pb}(\mathrm{II})$ ion is eight-coordinated with four nitrogen atoms of the two phen ligands and four oxygen atoms of the two nitrate
radical anions.

Key Words: Plumbum(II) complex, 1,10-Phenanthroline, Crystal structure.

Because of their rich structure and versatility, the design and synthesis of the phen(1,10-phenanthroline) coordinated complexes have attracted considerable interest in recent years ${ }^{1-4}$. They have potential applications in biological activity, electrochemistry, spectrum and fluorescent, catalysis and molecular magnetism ${ }^{2,3,6-9}$.

In this paper, we report the synthesis and $\mathrm{X}$-ray structure of a ternary plumbum complex $\left[\mathrm{Pb}(\text { phen })_{2}\left(\mathrm{NO}_{3}\right)_{2}\right]$.

All reagents were of AR grade and used without further purification. IR spectra were recorded on a Nexus- 870 spectrophotometer. The crystal structure was determined by Siemens SMART CCD area-detector diffractometer.

Synthesis of $\left[\mathrm{Pb}(\text { phen })_{2}\left(\mathrm{NO}_{3}\right)_{2}\right]$ : A solution of $10 \mathrm{mmol}$ of 1,10-phenanthroline in $10 \mathrm{~mL}$ ethanol, a solution of $5 \mathrm{mmol}$ $\mathrm{Pb}\left(\mathrm{NO}_{3}\right)_{2}$ in $10 \mathrm{~mL}$ water and a solution of $5 \mathrm{mmol}$ sodium ethylene glycol-bis-(2-amino-ethylether)-N,N,N',N'-tetraacetate in $10 \mathrm{~mL}$ water were mixed together under stirring for $2 \mathrm{~h}$. After being filtered, the solution was kept at room condition for $6 \mathrm{~d}$ and then the well-shaped colourless four edges column single crystals were obtained. Yield $32 \%$. IR spectrum $(\mathrm{KBr}$, $\left.v_{\max }, \mathrm{cm}^{-1}\right): 3500,3420 ; 1630,1560,1420,847,717,619$.

Crystal structure determination: A single crystal $(0.45$ $\mathrm{mm} \times 0.20 \mathrm{~mm} \times 0.10 \mathrm{~mm}$ ) was selected for crystallographic data collection at 298(2) $\mathrm{K}$ and structure determinated with graphite monochromatic $\mathrm{MoK}_{\alpha}$ radiation $(\lambda=0.71073 \AA)$. A total of 11276 reflections were collected in the range of $1.55^{\circ}$ $\leq \theta \leq 25.02^{\circ}$, of which 4091 reflections were unique with $\mathrm{R}_{\text {int }}=0.0742$ and $\mathrm{R}=0.0306$ and $\mathrm{w} R=0.0574$, where

\begin{tabular}{ccccc}
\hline \multicolumn{5}{c}{ TABLE-1 } \\
NON-HYDROGEN ATOMIC COORDINATES $\left(\times 10^{4}\right)$ \\
AND THERMAL PARAMETERS $\left(\times 10^{3} \AA^{2}\right)$ \\
\hline Atom & $\mathrm{X}$ & $\mathrm{Y}$ & $\mathrm{Z}$ & $\mathrm{U}(\mathrm{eq})$ \\
\hline $\mathrm{Pb}(1)$ & $5028(1)$ & $3714(1)$ & $2394(1)$ & $35(1)$ \\
$\mathrm{N}(1)$ & $4482(3)$ & $3435(6)$ & $3646(2)$ & $35(1)$ \\
$\mathrm{N}(2)$ & $6006(3)$ & $2506(6)$ & $3418(2)$ & $36(1)$ \\
$\mathrm{N}(3)$ & $5839(3)$ & $1789(6)$ & $1571(2)$ & $40(1)$ \\
$\mathrm{O}(1)$ & $6348(3)$ & $5641(6)$ & $2281(2)$ & $68(1)$ \\
$\mathrm{O}(2)$ & $5687(3)$ & $6620(6)$ & $3118(2)$ & $67(1)$ \\
$\mathrm{C}(1)$ & $3752(4)$ & $3918(8)$ & $3768(3)$ & $45(2)$ \\
$\mathrm{C}(2)$ & $3481(4)$ & $3821(8)$ & $4459(3)$ & $52(2)$ \\
\hline \multicolumn{5}{r}{}
\end{tabular}

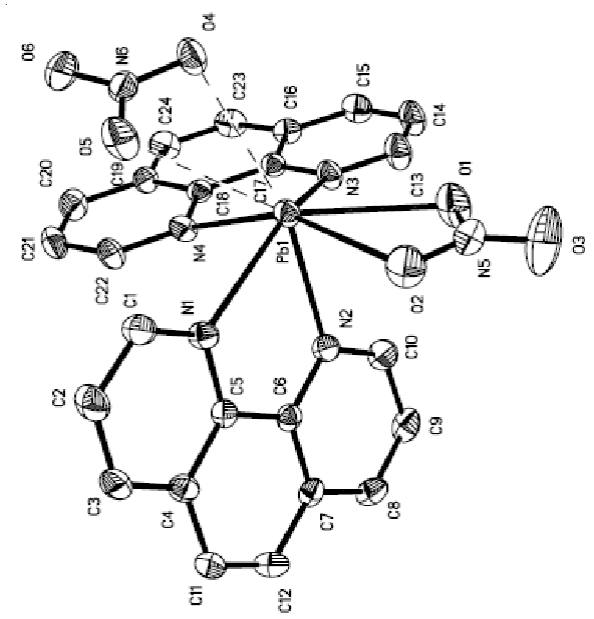

Fig. 1. Molecular structure of the complex $\left[\mathrm{Pb}(\mathrm{phen})_{2}\left(\mathrm{NO}_{3}\right)_{2}\right]$ 
TABLE-2

SELECTED BOND LENGTHS $(\AA \AA)$ AND BOND ANGLES $\left({ }^{\circ}\right)$

\begin{tabular}{|c|c|c|c|c|c|}
\hline Bond & Length & Angle & $\left({ }^{\circ}\right)$ & Angle & $\left({ }^{\circ}\right)$ \\
\hline $\mathrm{Pb}(1)-\mathrm{N}(1)$ & $2.574(4)$ & $\mathrm{N}(2)-\mathrm{Pb}(1)-\mathrm{N}(1)$ & $65.59(14)$ & $\mathrm{O}(1)-\mathrm{Pb}(1)-\mathrm{O}(2)$ & $46.20(13)$ \\
\hline $\mathrm{Pb}(1)-\mathrm{N}(2)$ & $2.477(4)$ & $\mathrm{N}(2)-\mathrm{Pb}(1)-\mathrm{N}(4)$ & $82.25(14)$ & $\mathrm{O}(2)-\mathrm{Pb}(1)-\mathrm{O}(5)$ & $118.76(13)$ \\
\hline $\mathrm{Pb}(1)-\mathrm{O}(1)$ & $2.698(4)$ & $\mathrm{N}(1)-\mathrm{Pb}(1)-\mathrm{O}(1)$ & $120.72(13)$ & $\mathrm{C}(1)-\mathrm{N}(1)-\mathrm{Pb}(1)$ & $125.1(3)$ \\
\hline $\mathrm{Pb}(1)-\mathrm{O}(2)$ & $2.757(4)$ & $\mathrm{N}(1)-\mathrm{Pb}(1)-\mathrm{O}(2)$ & $79.44(14)$ & $\mathrm{C}(6)-\mathrm{N}(2)-\mathrm{Pb}(1)$ & $120.2(3)$ \\
\hline $\mathrm{N}(5)-\mathrm{O}(1)$ & $1.243(6)$ & $\mathrm{O}(1)-\mathrm{Pb}(1)-\mathrm{O}(2)$ & $46.20(13)$ & $\mathrm{O}(3)-\mathrm{N}(5)-\mathrm{O}(1)$ & $121.8(7)$ \\
\hline
\end{tabular}

$\mathrm{w}=1 /\left[\mathrm{s}^{2}\left(\mathrm{~F}_{0}{ }^{2}\right)+(0.0137 \mathrm{P})^{2}+0.0000 \mathrm{P}\right], \mathrm{P}=\left(\mathrm{F}_{0}{ }^{2}+2 \mathrm{~F}_{0}{ }^{2}\right) / 3$. The maximum and minimum peaks on the final difference Fourier map are corresponding to 1.881 and $-1.327 \mathrm{e} / \AA^{3}$ (CCDC No. 908532), respectively.

The atomic coordinates and thermal parameters are listed in Table- 1 and the selected bond lengths and bond angles in Table-2, respectively. Fig. 1 shows diagram of the molecular structure of the complex $\left[\mathrm{Pb}(\mathrm{phen})_{2}\left(\mathrm{NO}_{3}\right)_{2}\right]$. Fig. 2 shows a perspective view of the crystal packing in the unit cell. As shown in the Fig. 1, the center plumbum(II) cation is eightcoordinated with four nitrogen atoms of the two phen ligands and four oxygen atoms of the two nitrate radical anions.

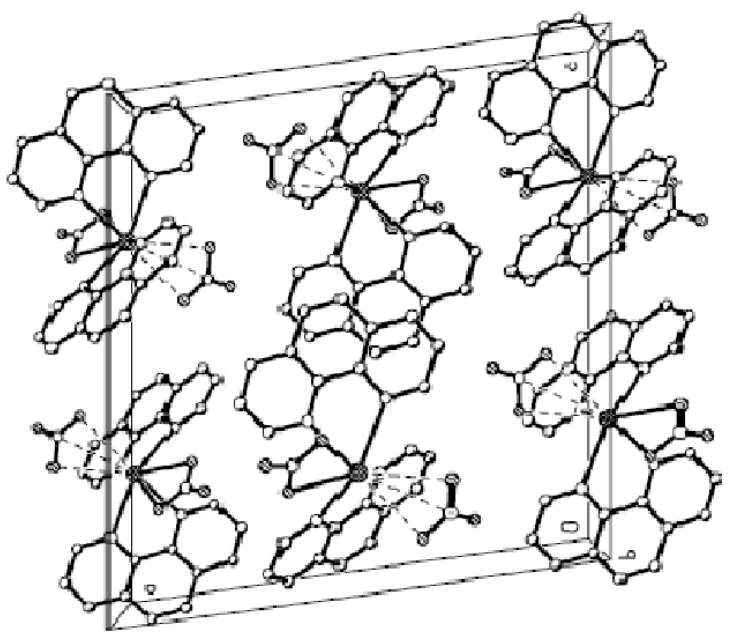

Fig. 2. Molecular packing arrangement in the unit cell

\section{ACKNOWLEDGEMENTS}

This work is financially supported by the Natural Science Foundation of Anhui Province (Nos. 1308085MB23), the National Natural Science Foundation of China (Nos. 20871039 and 21101053) and the Nature Science Foundation of Anhui Universities (KJ2011Z301).

\section{REFERENCES}

1. K.H. Thebo, H.A. Shad, J. Raftery, M.A. Malik, T. Mahmud and P. O’Brien, J. Mol. Struc., 1001, 12 (2011).

2. H.Z. Dong, W.B. Tao, J.H. Bi, V. Milway, Z.Q. Xu, S.Y. Zhang, X.C. Meng, W.T. Bi, J. Li and M. Li, Nanoscale Res. Lett., 6, 484 (2011).

3. S.R. Chowdhury, M.D. Selim, S. Chatterjee, S. Igarashi, Y. Yukawa and K.K. Mukherjea, J. Coord. Chem., 65, 3469 (2012).

4. J.H. Bi, B.Z. Li, Z.X. Huan and J. Li, Asian J. Chem., 22, 7443 (2010).

5. P.R. Reddy, A. Shilpa, N. Raju and P. Raghavaiah, J. Inorg. Biochem., 105, 1603 (2011).

6. S.J. Wang, J. Milam, A.C. Ohlin, V.H. Rambaran, E. Clark, W. Ward, L. Seymour, W.H. Casey, A.A. Holder and W. Miao, Anal. Chem., 81, 4068 (2009).

7. Y.A. Bryleva, T.E. Kokina, E.M. Uskov, L.A. Glinskaya, O.V. Antonova and S.V. Larionov, Russ. J. Coord. Chem., 39, 41 (2013).

8. A.K. Singh, S.K. Singh, H. Mishra, R. Prakash and S.B. Rai, J. Phys. Chem. B, 144, 13042 (2010).

9. I. Boldog, F.J. Munoz-Lara, A.B. Gaspar, M.C. Muñoz, M. Seredyuk and J.A. Real, Inorg. Chem., 48, 3710 (2009). 